\title{
Biogeochemical evidence for hydrologic changes during the Holocene in a lake sediment record from southeast Greenland
}

\author{
Nicholas L Balascio, ' William J D'Andrea, ${ }^{2}$ Raymond S Bradley' and \\ Bianca B Perren ${ }^{3}$
}

\begin{abstract}
Holocene paleoclimate records from Greenland help us understand the response of the Greenland Ice Sheet and regional oceanic and atmospheric circulation systems to natural climate variability in order to place recent changes in a longer-term perspective. Here biogeochemical analysis of a lake sediment core from southeast Greenland is used to define changes in moisture balance and runoff during the Holocene in a catchment near the margin of the Greenland Ice Sheet. A $1.6 \mathrm{~m}$ sediment core that spans the last 8.8 ka was recovered from Flower Valley Lake on Ammassalik Island. Magnetic susceptibility, diatoms, bulk biogeochemical properties (TOC, $\mathrm{C} / \mathrm{N}, \delta^{13} \mathrm{C}_{\text {org }}$ ), and lipid biomarkers ( $n$-alkanes; $\mathrm{C}_{16}-\mathrm{C}_{31}$ ) reveal changes in clastic sedimentation and the relative input of terrestrial- and aquatic-derived organic matter. Hydrogen isotope values $(\delta D)$ of mid- $\left(n-C_{25}\right)$ and long-chain $(n-$ $\left.C_{29}, n-C_{31}\right) n$-alkanes allow reconstruction of $\delta D$ of precipitation and summertime evaporation of lake water. Following a period of early lake ontogeny and landscape stabilization after deglaciation from 8.4 to $7.0 \mathrm{ka}$, the mid Holocene, 8.4-4.I ka, is characterized by greater evaporative enrichment of the lake water as indicated by $\delta D$ records. After 4.1 ka, there is a decrease in evaporative enrichment of the lake water. There is also an abrupt transition to more variable sedimentation marked by sharp increases in magnetic susceptibility, $\mathrm{C} / \mathrm{N}, \delta^{13} \mathrm{C}_{\text {org }}$, and the concentration of long-chain $n$-alkanes, showing periodic delivery of terrestrial organic matter and clastic sediment to the lake. Higher insolation during the mid Holocene resulted in a warmer and drier climate with longer ice-free periods in the summer and enhanced evaporation of lake water. The reduction in insolation and colder temperatures during the late Holocene caused a reduction in evaporation of lake water over the last $4.1 \mathrm{ka}$ and was accompanied by periodic increases in surface runoff, which correspond with intervals of cold Greenland Ice Sheet surface temperatures.
\end{abstract}

\section{Keywords}

biogeochemistry, diatoms, Greenland, Holocene, lake sediment, paleoclimate

Received 27 February 2013; revised manuscript accepted 3 April 2013

\section{Introduction}

The Arctic is currently undergoing dramatic environmental changes. These are reflected in the hydrologic cycle (Peterson et al., 2002; Rawlins et al., 2010), sea-ice extent (Stroeve et al., 2007), oceanic circulation (Morison et al., 2012; Polyakov et al., 2005), glacier retreat (Gardner et al., 2011), and the changing dynamics of the Greenland Ice Sheet (Howat et al., 2007; Luthcke et al., 2006; Rignot and Kanagaratnam, 2006). To assess the severity of these observed changes and evaluate the future response of these systems, it is necessary to place recent conditions into a longer-term context. Long-term climate observations from the Arctic are limited, therefore geologic records from marine and terrestrial environments must be used to understand the natural variability of these systems (e.g. Funder et al., 2011a; Kaufman et al., 2004, 2009; Kinnard et al., 2011; Miller et al., 2010; Spielhagen et al., 2011; Vinther et al., 2009).

Our understanding of climate around Greenland is important because of the potential contribution of the ice sheet to future sealevel rise and because of the influence of ocean and atmospheric circulation systems, which have a role in regulating regional climate and have interactions at the ice sheet margins. Greenland has also been experiencing unprecedented recent melting (Chen et al., 2006), making an understanding of regional climate dynamics even more important. This study focuses on Holocene climate conditions of southeast Greenland. At the southeast Greenland shelf the East Greenland Current interacts with the Irminger Current
(Figure 1). The southward flowing East Greenland Current transports cold fresh water along the Greenland margin and is a major pathway for sea-ice export from the Arctic Ocean. The Irminger Current flows northwest carrying warm saline subtropical water to the region and is a branch of the North Atlantic Current. Today, these subtropical waters extend into fjords along the coast of southeast Greenland, and an increase in heat exchange via this current system is a proposed mechanism for the recent acceleration in the retreat of the region's fjord glaciers (Seale et al., 2011; Straneo et al., 2010).

The Holocene climate history of the region is marked initially by the retreat of the ice sheet from the southeast Greenland continental shelf. The ice sheet continued to retreat behind its present margins during the Holocene Thermal Maximum, c. 8-5 ka BP, and then began re-advancing during the Neoglacial, with a maximum

\footnotetext{
'University of Massachusetts, USA

${ }^{2}$ Lamont-Doherty Earth Observatory of Columbia University, USA

${ }^{3}$ Université de Franche-Comté, France
}

\section{Corresponding author:}

Nicholas L Balascio, Climate System Research Center, Department of Geosciences, University of Massachusetts, 6I I North Pleasant Street, Amherst MA 01003, USA.

Email: balascio@geo.umass.edu 

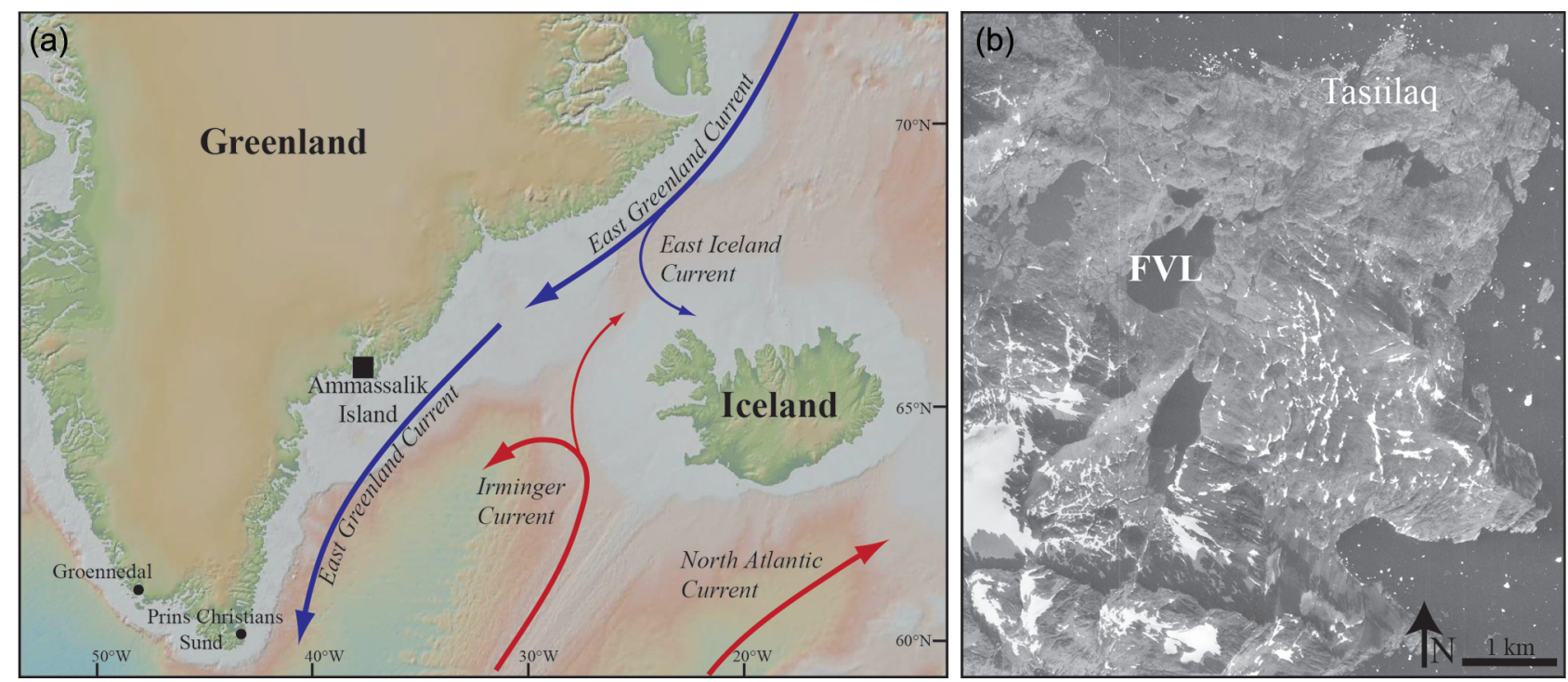

Figure I. (a) Location of Ammassalik Island in southeast Greenland and generalized pathways of major ocean currents that influence climate of the region (basemap from Ryan et al., 2009). (b) Aerial photograph of Flower Valley Lake (FVL) located on the southern end of Ammassalik Island $\sim 1.5 \mathrm{~km}$ from the town of Tasiilaq.

extent during the late 1800 s to early 1900 s (Funder et al., 2011b). Changes in ocean dynamics during the Holocene are documented by marine records from the southeast Greenland shelf, which provide evidence for oceanographic changes during the Holocene thermal maximum and Neoglacial period (e.g. Andersen et al., 2004; Andrews et al., 1997; Jennings et al., 2002, 2011). However, there is little information about terrestrial environmental conditions from the region.

The goal of this study is to reconstruct terrestrial climate conditions during the Holocene using a lake sediment record from the coast of southeast Greenland. We focus on the organic matter characteristics of the sediment, including results from the analysis of aquatic microfossils, bulk biogeochemical properties (TOC, $\mathrm{C} / \mathrm{N}, \delta^{13} \mathrm{C}$ ), and the concentrations and hydrogen isotopic composition of sedimentary leaf waxes ( $n$-alkanes). These parameters provide information on lake ontogeny following deglaciation, changes in the source and delivery of organic matter to the lake, and hydrologic changes related to oceanic and atmospheric dynamics during the Holocene.

\section{Organic and biogeochemical analysis of lake sediments}

Organic matter in lakes derive from terrestrial and aquatic sources and can be used to reconstruct changes in landscape vegetation, aquatic productivity, and the relative input from autochthonous and allochthonous sources (Meyers, 2003). Rapid, high-resolution organic geochemical characteristics of a sediment sequence can be assessed by measuring bulk organic matter properties such as, total organic carbon (TOC), total nitrogen (TN), and the carbon isotopic composition of organic carbon $\left(\delta^{13} \mathrm{C}\right)$, which provide information on changes in primary productivity and relative contributions of aquatic- and terrestrial-derived organic matter (Meyers, 2003)

Aquatic microfossils are another useful component of sedimentary organic matter that can be used to investigate lacustrine paleoenvironmental conditions. In this study, we identify changes in the concentration and relative abundance of planktonic and benthic diatom species. Downcore diatom assemblages are used to assess changes in lake water $\mathrm{pH}$, temperature, and nutrient availability (Smol and Stoermer, 2010). In the Arctic, freshwater diatom assemblages are used to track changing ice cover regimes (Douglas et al., 1994; Perren et al., 2012b), Holocene lake development and evolution (Fritz et al., 2004; Wilson et al., 2012), as well the in-lake response to changing effective moisture (Perren et al., 2012a).

Greater detail about sedimentary organic matter in lakes can be gained through the analysis of lipid biomarkers (Castañeda and Schouten, 2011). Here we focus on the analysis of $n$-alkanes, aliphatic hydrocarbons that are stable at low temperatures and resistant to microbial degradation (Meyers, 2003). They are produced by algae, photosynthetic bacteria, and aquatic plants living in the lake, as well as terrestrial plants living in the catchment (Meyers, 2003). Long-chain $n$-alkanes tend to dominate terrestrial leaf waxes, short-chain $n$-alkanes are more characteristic of algae, and mid-chain length $n$-alkanes are characteristic of aquatic macrophytes (Cranwell et al., 1987; Eglinton and Hamilton, 1967; Ficken et al., 2000; Hou et al., 2006; Meyers, 2003).

The hydrogen isotopic composition $(D / H ; \delta D$ using the delta notation) of leaf wax $n$-alkanes reflects the $D / H$ of source water used by a plant after modification by evaporation and biosynthetic fractionation (Kahmen et al., 2013a,b; Sachse et al., 2004, 2012), and can therefore be a powerful tool for paleohydrologic reconstruction. The movement of water through the hydrologic cycle (Dansgaard, 1964), as well as regional and seasonal climatological conditions (Bowen and Revenaugh, 2003), results in the stable isotopes $\left(D / H\right.$ and $\left.{ }^{18} \mathrm{O} /{ }^{16} \mathrm{O}\right)$ of local precipitation. Algae and macrophytes incorporate hydrogen from lake water while terrestrial plants use hydrogen from soil moisture; both water sources are ultimately derived from local precipitation. Therefore, $\delta D$ of different $n$-alkanes can be used to reconstruct the climatic factors controlling the isotopic composition of lake water and precipitation through time.

\section{Study area}

Flower Valley Lake $\left(65^{\circ} 36.64^{\prime} \mathrm{N} 37^{\circ} 41.61^{\prime} \mathrm{W} ; 73 \mathrm{~m}\right.$ a.s.1.; 0.7 $\mathrm{km}^{2}$ ) is located $2.5 \mathrm{~km}$ southwest from the town of Tasiilaq on Ammassalik Island, southeast Greenland (Figure 1). It is immediately downvalley of an east-facing cirque that contains a smaller lake. The main inlet is on the southern edge of the lake where there is a prominent alluvial fan. The lake is deepest near its western side and is shallower near the outlet at the eastern edge. There is no glacier ice in the catchment today, although glaciers are present in the valley just north of the lake where peak elevations are higher. Southeast Greenland is within the Low Arctic 
vegetation zone (Walker et al., 2005). Modern vegetation in the area consists mainly of dwarf shrubs, sedge, herbs, moss, and grasses (Daniëls et al., 2011).

Weather station data from Tasiilaq, recorded since AD 1895 , shows that monthly average temperatures range from $-7^{\circ} \mathrm{C}$ in winter to $6^{\circ} \mathrm{C}$ in summer and average annual precipitation is 870 $\mathrm{mm}$ (Figure 2) (Cappelen et al., 2011). The range of modern precipitation isotopes for the region can be estimated by examining data from stations participating in the Global Network of Isotopes in Precipitation (GNIP) (IAEA/WMO, 2006). The two closest GNIP stations, Prins Christians Sund $\left(60.03^{\circ} \mathrm{N} 43.12^{\circ} \mathrm{W}, 76 \mathrm{~m}\right.$ a.s.1.) and Groennedal $\left(61.22^{\circ} \mathrm{N} 48.12^{\circ} \mathrm{W}, 27 \mathrm{~m}\right.$ a.s.1.), are located along the coast of southern Greenland and experience similar climate conditions (Figure 1). $\delta D$ values measured on samples from the Prins Christians Sund station ranged from -47 to $-86 \%$ between March and November, however the data set is discontinuous and only incorporates two years of measurements, 1976 and 1978. $\delta D$ measurements from the Groennedal station were more continuous, 1962-1967 and 1972-1974, and values ranged from -42 to $-134 \%$. Surface water samples collected during July 2012 from four lakes in the region, including from Flower Valley Lake, show a $\delta D$ range from -96 to $-117 \%$ (Table 1 ).

\section{Methods}

\section{Sediment core collection and sampling}

Sediment cores were extracted from Flower Valley Lake (FVL) in April 2010 when the lake was ice covered. Bathymetric measurements were made manually through holes drilled in the ice and sediment cores were recovered from the deepest location, which has a water depth of $27 \mathrm{~m}$. A $30 \mathrm{~cm}$ surface core, FVL-10D, and a $159 \mathrm{~cm}$ percussion core, FVL-10N were collected. The surface core was extruded in the field into sample bags. The upper $15 \mathrm{~cm}$ of FVL$10 \mathrm{D}$ was sampled at $0.5 \mathrm{~cm}$ intervals and the lower $15 \mathrm{~cm}$ was sampled at $1 \mathrm{~cm}$ intervals. In the laboratory, sediment from FVL-10D

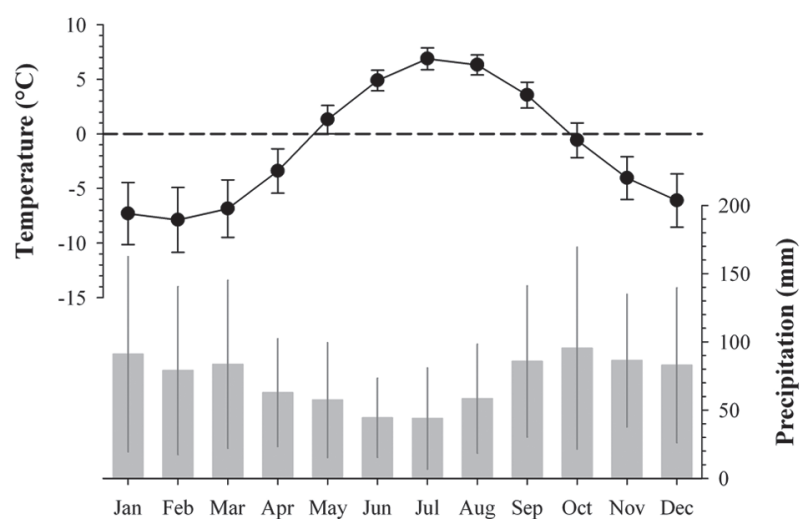

Figure 2. Historic weather data from Tasiilaq. Average monthly temperatures are based on data from 1895 to 2010 and average monthly precipitation totals are based on data from 1898 to 2010 (Cappelen et al., 20I I). Error bars indicate I $\sigma$ ranges for monthly values. was subsampled for ${ }^{210} \mathrm{~Pb}$ and bulk biogeochemical analysis. FVL$10 \mathrm{~N}$ was split, scanned every $0.5 \mathrm{~cm}$ using a Bartington MS2E magnetic susceptibility sensor, sampled for radiocarbon analysis, and then sampled every $1 \mathrm{~cm}$ for biogeochemical measurements. The $159 \mathrm{~cm}$ composite record was created by aligning bulk organic geochemical data collected on samples from both cores, which show changes associated with a prominent turbidite layer.

\section{Chronology}

The chronology for the record was determined based on ${ }^{210} \mathrm{~Pb}$ analysis of the upper sediments and AMS radiocarbon measurements on plant macrofossils. The ${ }^{210} \mathrm{~Pb}$ activity was measured on $0.5-0.7 \mathrm{~g}$ of dry sediment taken at $1 \mathrm{~cm}$ intervals from the upper $10 \mathrm{~cm}$ of the record by Flett Research Ltd. (Winnipeg, Canada) (Table 2). Ten AMS radiocarbon samples were picked from the core surface or wet sieved with deionized water. All radiocarbon ages were calibrated to calendar years using CALIB v. 6.0 (Stuiver and Reimer, 1993) with the IntCal09 calibration data set (Reimer et al., 2009). Ages are presented in calendar years prior to AD 1950 (BP) unless otherwise indicated. An age-depth model using all of the chronologic information was created in $\mathrm{R}(\mathrm{R}$ Development Core Team, 2011) using the Clam routine (Blaauw, 2010). Smooth spline functions, weighted by the probability distributions of the calibrated age ranges, were fitted to the ages and the best-fit function is presented and 95\% confidence age ranges are discussed (Blaauw, 2010).

\section{Diatom analysis}

Diatom assemblages were analyzed from 32 samples taken every $5 \mathrm{~cm}$ from core FVL-10N. Sediments were prepared from freezedried material following standard oxidative procedures using $\mathrm{H}_{2} \mathrm{O}_{2}$ (Renberg, 1990). Divinylbenzene (DVB) spheres of a known quantity were added to the resultant slurries to estimate sedimentary diatom concentration (Battarbee and Kneen, 1982). Slides were prepared using Naphrax mounting medium and diatom valves were identified and enumerated using light microscopy at $1000 \times$ under oil immersion. At least 350 valves were identified and counted from each interval. Principal component analysis (PCA) was performed on centered percentage assemblage data. PCA was chosen because the species assemblages over time were relatively stable and thus had a detrended correspondence analysis gradient length less than 2.

\section{Bulk organic geochemical analysis}

Bulk organic geochemical analysis was performed on all sampled depth intervals from both cores. Subsamples were freezedried, acidified with $10 \%$ hydrochloric acid, and analyzed for total organic carbon (TOC), total nitrogen (TN), and $\delta^{13} \mathrm{C}$ on a Costech ECS 410 Elemental Analyzer interfaced with a Thermo Delta V Advantage IRMS. Isotopic values are reported in per mille (\%o) notation relative to VPDB for $\delta^{13} \mathrm{C}$. Uncertainty in TOC and TN, measurements are $\pm 0.2 \%$ and $\pm 0.3 \%$ for $\delta^{13} \mathrm{C}$ based on triplicate analysis. $\mathrm{C} / \mathrm{N}$ values were calculated as the molar ratio of TOC to TN.

Table I. Water isotope data from surface water collected from four lakes around Ammassalik Island in July 2012.

\begin{tabular}{llllll}
\hline Lake & Latitude $\left({ }^{\circ} \mathrm{N}\right)$ & Longitude $\left({ }^{\circ} \mathrm{W}\right)$ & Elevation $(\mathrm{m})$ & $\delta^{18} \mathrm{O}(\% \circ)$ & $\delta D(\% \circ)$ \\
\hline Nanererserpik & 65.91206 & 37.14567 & 47 & $-15.4 \pm 0.1$ & $-116.8 \pm 0.2$ \\
Lower Sermilik & 65.64449 & 37.72621 & 61 & $-15.0 \pm 0.1$ & $-110.3 \pm 0.1$ \\
Flower Valley & 65.61068 & 37.69348 & 73 & $-14.4 \pm 0.1$ & $-105.5 \pm 0.0$ \\
Kulusuk & 65.56028 & 37.11424 & 190 & $-13.3 \pm 0.1$ & $-96.1 \pm 0.1$ \\
\hline
\end{tabular}


Table 2. Chronologic data used to construct the age model for the Flower Valley Lake record. Radiocarbon results were calibrated with CALIB 6.0 using the INTCAL09 data set.

\begin{tabular}{|c|c|c|c|c|c|c|}
\hline \multirow{2}{*}{$\begin{array}{l}\text { Core depth } \\
(\mathrm{cm})\end{array}$} & \multirow[t]{2}{*}{ Description } & \multirow{2}{*}{$\begin{array}{l}\text { Laboratory } \\
\text { ID }^{\mathrm{a}}\end{array}$} & \multirow{2}{*}{$\begin{array}{l}{ }^{14} \mathrm{C} \text { age } \\
\text { (yr BP) }\end{array}$} & \multicolumn{2}{|c|}{ Calibrated age range (yr BP) } & \multirow{2}{*}{$\begin{array}{l}\text { Median age } \\
\text { (cal.yr BP) }\end{array}$} \\
\hline & & & & $(\mathrm{I} \sigma)$ & $(2 \sigma)$ & \\
\hline 0 & Core top & & & & & $-60^{b}$ \\
\hline 3.5 & ${ }^{210} \mathrm{~Pb}$ & & & & & $100^{c}$ \\
\hline 12 & Plant/wood & UCI-8938I & $1140 \pm 25$ & $983-1067$ & $970-1168$ & 1029 \\
\hline 29 & Plant/wood & OS-8964I & $1970 \pm 35$ & $1879-1967$ & |829-1994 & 1921 \\
\hline 36 & Plant/wood & UCI-89382 & $2080 \pm 20$ & $200 I-2100$ & $1995-2116$ & 2048 \\
\hline 54 & Plant/wood & UCI-87237 & $1885 \pm 20$ & $182|-| 866$ & $\mid 738-1882$ & $|84|$ \\
\hline 63 & Plant/wood & OS-89642 & $2180 \pm 35$ & $2131-2304$ & $2068-2322$ & 2226 \\
\hline 78 & Plant/wood & UCI-87238 & $3145 \pm 20$ & $3358-3387$ & $3338-344 I$ & 3374 \\
\hline 103 & Plant/wood & UCl-89383 & $4010 \pm 30$ & $4435-4519$ & $4418-4566$ & 4479 \\
\hline 122 & Plant/wood & UCI-89384 & $5575 \pm 30$ & $6316-6397$ & $630 \mathrm{I}-6407$ & 6356 \\
\hline 146 & Plant/wood & UCI-87239 & $7540 \pm 80$ & $8214-8416$ & $8|80-85| 4$ & 8348 \\
\hline 151 & Plant/wood & UCl-89385 & $7375 \pm 25$ & $8168-8287$ & $8057-8313$ & 8194 \\
\hline
\end{tabular}

Notes: aUCl: University of California Irvine Keck-CCAMS Facility; OS: National Ocean Sciences Accelerator Mass Spectrometry Facility.

bYear of sediment core collection (AD 20I0).

c210 Pb-based age (AD 1850).

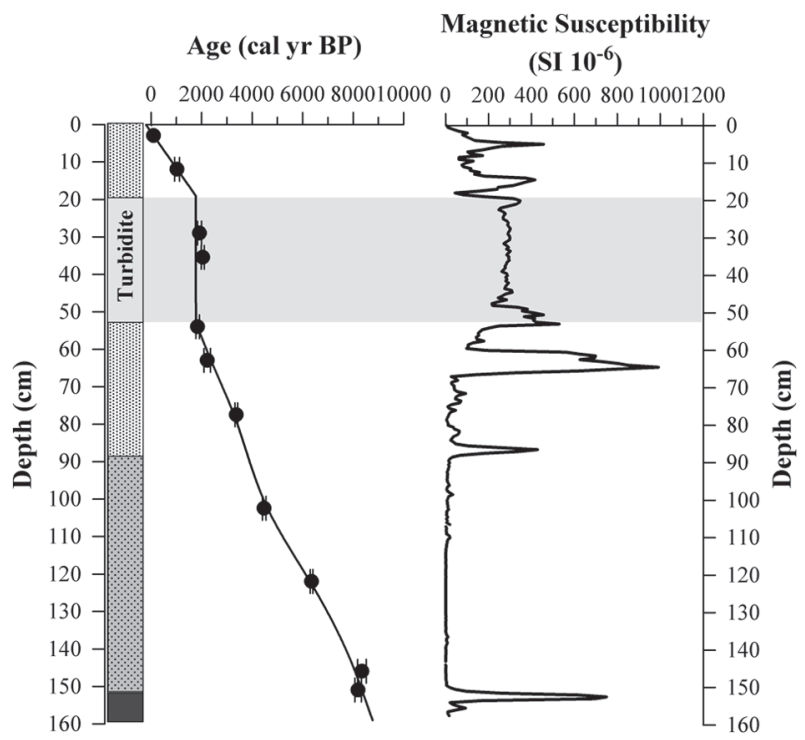

Figure 3. Sediment stratigraphy and age-depth model for the composite sediment record. The age-depth model is based on a smooth spline function fitted using the Clam routine (Blaauw, 2010). The $2 \sigma$ calibrated age ranges are indicated by error bars on the radiocarbon dates.

\section{Sedimentary n-alkanes}

Lipid biomarkers were analyzed in $2 \mathrm{~cm}$ thick samples taken every $10 \mathrm{~cm}$ from core FVL-10N. Lipids were extracted from ground and freeze-dried samples with 9:1 (v:v) dichloromethane:methanol using a Dionex Accelerated Solvent Extractor (ASE 200). The total lipid extract was separated using flash column chromatography over silica gel. Approximately 0.75 $\mathrm{g}$ of silica gel (70-230 mesh) was packed in a Pasteur pipette and pre-cleaned with 4 bed volumes each of methanol, dichloromethane, and hexane (Optima grade, Fisher Scientific). TLE was loaded with hexane onto hexane-saturated columns and eluted with 4 bed volumes each of hexane, dichloromethane and methanol. The first fraction (hexane eluent) was evaporated and brought up in toluene with heptatriacontane as internal standard and transferred to a GC vials for quantification of $n$-alkanes $\left(\mathrm{C}_{15}-\mathrm{C}_{33}\right)$ on an Agilent $6890 \mathrm{~N}$ gas chromatograph-flame ionization detector (GC-FID) and identification of $n$-alkanes in representative samples on an HP6890 GC-mass selective detector (MSD). Average chain length (ACL) was determined using the formula

$$
\mathrm{ACL}=\frac{21 \mathrm{C}_{21}+23 \mathrm{C}_{23}+25 \mathrm{C}_{25}+27 \mathrm{C}_{27}+}{29 \mathrm{C}_{29}+31 \mathrm{C}_{31}+33 \mathrm{C}_{33}}
$$

where $\mathrm{C}_{x}$ is $\mu \mathrm{g} / \mathrm{g}$ sediment of the $n$-alkane with $x$ carbon atoms. Carbon Preference Index (CPI) was calculated using the formula

$$
\mathrm{CPI}=\frac{1}{2}\left[\begin{array}{l}
\frac{\mathrm{C}_{21}+\mathrm{C}_{23}+\mathrm{C}_{25}+\mathrm{C}_{27}+\mathrm{C}_{29}+\mathrm{C}_{31}+\mathrm{C}_{33}}{\mathrm{C}_{22}+\mathrm{C}_{24}+\mathrm{C}_{26}+\mathrm{C}_{28}+\mathrm{C}_{30}+\mathrm{C}_{32}+\mathrm{C}_{34}} \\
\frac{\mathrm{C}_{21}+\mathrm{C}_{23}+\mathrm{C}_{25}+\mathrm{C}_{27}+\mathrm{C}_{29}+\mathrm{C}_{31}+\mathrm{C}_{33}}{\mathrm{C}_{20}+\mathrm{C}_{22}+\mathrm{C}_{24}+\mathrm{C}_{26}+\mathrm{C}_{28}+\mathrm{C}_{30}+\mathrm{C}_{32}}
\end{array}\right]
$$

The hydrogen isotope composition of $n$-alkanes is reported as per mil relative to VSMOW using standard $\delta$ notation:

$$
\delta D=\left(\frac{\frac{D}{H}}{\frac{D}{H_{\text {sample }}}}-1\right) \times 1000
$$

$\delta D$ values of $n$-alkanes $\left(\mathrm{C}_{25}-\mathrm{C}_{31}\right)$ were measured at the Stable Isotope Lab at LDEO on a Thermo Delta $\mathrm{V}$ isotope ratio mass spectrometer (irMS) coupled to a Thermo Trace GC via a ConFlo IV interface. Samples were measured in duplicate, triplicate or quadruplicate and precision of replicate analyses was typically better than $\pm 1.5 \%(1 \sigma)$. Analytical precision of an external standard measured after every sixth sample injection throughout the course of analysis was better than $\pm 3 \%$ ( $1 \sigma)$. Single-point anchoring with reference $\mathrm{H}_{2}$ gas was used to convert raw $\delta D$ measurements to the VSMOW scale. A laboratory standard (lipid mixture) calibrated to a lipid mixture with known $\delta D$ (F8; Arndt Schimmelmann, Indiana University) and measured after every sixth injection and used to determine $\delta D$ of reference $\mathrm{H}_{2}$.

\section{Results and discussion}

\section{Sediment stratigraphy and chronology}

The $159 \mathrm{~cm}$ long sediment record from Flower Valley Lake consists of three main lithostratigraphic units (Figure 3). The lowest 
$7 \mathrm{~cm}$ is a light gray clay that abruptly transitions into brown organic-rich sediment, which extends from 152 to $89 \mathrm{~cm}$. Above $89 \mathrm{~cm}$, the sediment is a lighter brown color with some darker color bands and layers containing coarse sediment. This upper unit also contains a large mass-movement deposit from 53 to 19.5 $\mathrm{cm}$, characterized by a basal sandy layer with abundant terrestrial macrofossils that fines upward into a $1 \mathrm{~cm}$ thick clay layer at 19.5 $\mathrm{cm}$. These general stratigraphic characteristics are reflected in magnetic susceptibility, where higher values reflect coarse minerogenic sediment (Figure 3). There is a distinct transition from low magnetic susceptibility values from 149 to $89 \mathrm{~cm}$ to higher and more variable values over the upper $89 \mathrm{~cm}$. These data and ${ }^{14} \mathrm{C}$ dates within the unit clearly define a turbidite deposit from 53 to $19.5 \mathrm{~cm}$.

A chronology for the record was established using ${ }^{210} \mathrm{~Pb}$ analysis and AMS radiocarbon measurements (Tables 2, 3). ${ }^{210} \mathrm{~Pb}$ analysis of the upper $10 \mathrm{~cm}$ showed that the total ${ }^{210} \mathrm{~Pb}$ activity

Table 3. Total ${ }^{210} \mathrm{~Pb}$ activity of the upper $9.5 \mathrm{~cm}$ of the composite Flower Valley Lake sediment record.

\begin{tabular}{ll}
\hline $\begin{array}{l}\text { Core depth } \\
(\mathrm{cm})\end{array}$ & $\begin{array}{l}\text { Total }{ }^{210} \mathrm{~Pb} \text { activity } \\
(\mathrm{dpm} / \mathrm{g})\end{array}$ \\
\hline 0.5 & $14.69 \pm 0.31$ \\
1.5 & $0.25 \pm 0.07$ \\
2.5 & $0.11 \pm 0.06$ \\
3.5 & $<0.1$ \\
4.5 & $<0.1$ \\
5.5 & $<0.1$ \\
6.5 & $<0.1$ \\
7.5 & $<0.1$ \\
8.5 & $<0.1$ \\
9.5 & $<0.1$ \\
\hline
\end{tabular}

declined rapidly from $14.7 \mathrm{dpm} / \mathrm{g}$ to below detection limits $(<1$ $\mathrm{dpm} / \mathrm{g}$ ) at $3.5 \mathrm{~cm}$ (Table 3). This indicates that there is little, if any, supported ${ }^{210} \mathrm{~Pb}$ activity in the sediments and that the last 160 years of sedimentation occurred within the upper $3.5 \mathrm{~cm}$, assuming zero ${ }^{210} \mathrm{~Pb}$ activity is reached after 7 half-lives of 22.3 years. Ten radiocarbon ages define the rest of the age-depth relationship and were used to develop the age-depth model (Table 2; Figure $3)$. Smooth spline functions were fitted to ages above and below the turbidite layer. The record spans the last $8.8 \mathrm{ka}$ and the $95 \%$ uncertainty ranges for the smooth spline functions average \pm 0.16 $\mathrm{ka}$. The average sedimentation rate is $0.018 \mathrm{~cm} / \mathrm{yr}(55 \mathrm{yr} / \mathrm{cm})$. The transition from clay to organic-rich sediment at $152 \mathrm{~cm}$ occurred at $8.4 \mathrm{ka}$ and the interval with low magnetic susceptibility occurred from 8.4 to $3.9 \mathrm{ka}$. The last $3.9 \mathrm{ka}$ was marked by more variable sediment characteristics, higher magnetic susceptibility values, and includes the turbidite deposit. Two radiocarbon ages within the turbidite further support the interpretation that this was a rapidly deposited interval, but that normal sedimentation resumed after $1.8 \mathrm{ka}$.

\section{Diatoms}

We identified 140 diatom species that are all similar to those identified in other freshwater lakes in Greenland with circumneutral $\mathrm{pH}$ (Figure 4). The PCA axis 1 explains $45 \%$ of the variance in the assemblage data. The earliest part of the record, from 8.8 to $7.0 \mathrm{ka}$, is dominated by small benthic species, including Fragilaria brevistriata, Fragilaria pseudoconstruens, and Fragilaria pinnata. There is a rapid transition after 7 $\mathrm{ka}$ to more planktonic forms, with an increase in the abundance of Aulacoseira lirata, Cyclotella stelligera, and Cyclotella rossii complex. There are only minor variations in species abundances after $7 \mathrm{ka}$, although there is a negative trend in relative frequency of Fragilaria brevistriata and the PCA axis 1, particularly after $3.8 \mathrm{ka}$.

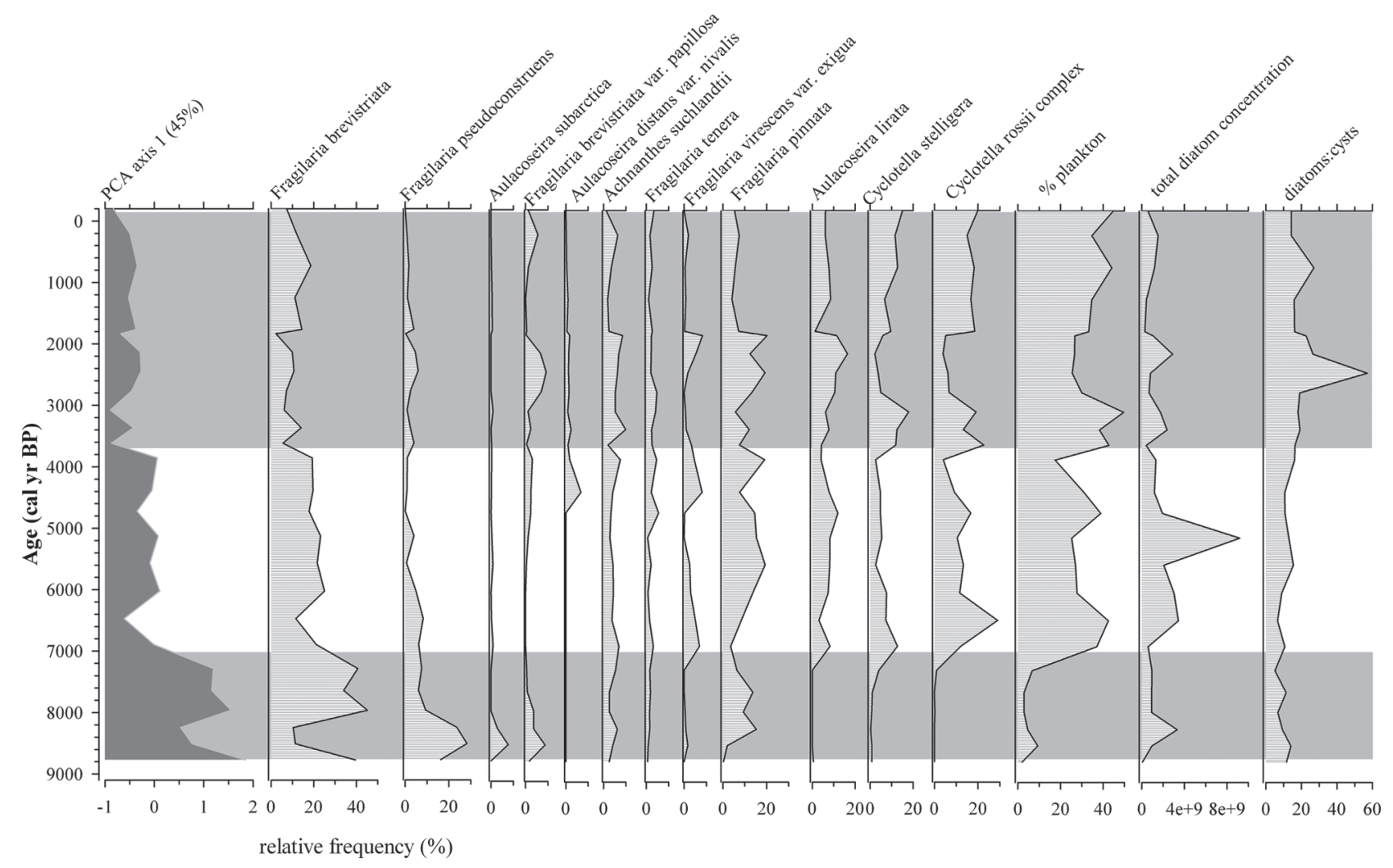

Figure 4. Summary of diatom analyses including: major diatom taxa, percentage of planktonic species, total diatom concentration, and the diatom:cyst ratio. Gray bars indicate intervals of assemblage changes. 


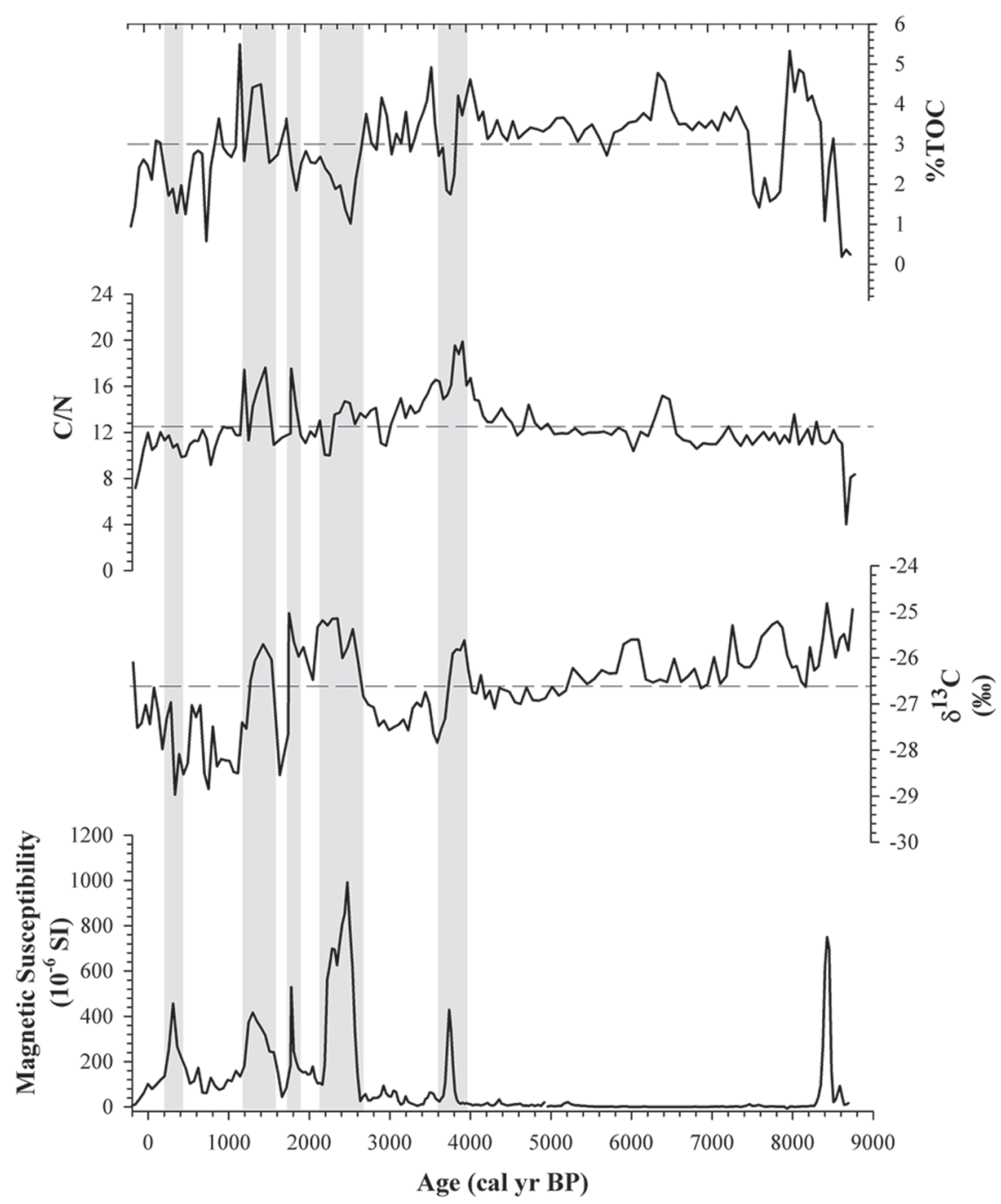

Figure 5. Magnetic susceptibility, $\% \mathrm{TOC}, \mathrm{C} / \mathrm{N}$, and $\delta^{13} \mathrm{C}$ for the composite record. Dashed lines indicate the mean $\% \mathrm{TOC}, \mathrm{C} / \mathrm{N}$, and $\delta^{13} \mathrm{C}$ values. Gray bars indicate intervals of greater input of clastic sediment and terrestrial-derived organic matter.

Diatom assemblages reflect limnic conditions associated with lake water $\mathrm{pH}$, temperature, and nutrient availability, which change through time due to lake ontogeny and climatic influences (Smol and Stoermer, 2010). In Flower Valley Lake, the early establishment of small benthic diatoms $(8.8-7.0 \mathrm{ka})$ is typical of lakes in recently deglaciated landscapes with poorly developed soil cover and higher $\mathrm{pH}$. The increase in planktonic species after 7 ka follows initial landscape stabilization and decrease of inorganic sedimentation. The trend in benthic diatoms and PCA axis 1 over the last $7 \mathrm{ka}$ are likely a response to a gradual decline in lake water $\mathrm{pH}$ owing to the greater input of dissolved inorganic carbon from progressive soil development in the catchment.

\section{Bulk organic geochemical analysis}

TOC, $\mathrm{C} / \mathrm{N}$, and $\delta^{13} \mathrm{C}$ results provide a high resolution record of changes in organic matter characteristics (Figure 5). The average TOC content is $3.1 \%$ with a range from $0.2 \%$ to $5.5 \%$. There are significant changes in TOC at the base of the record with increasing values from $8.8 \mathrm{ka}$ to $8.0 \mathrm{ka}$. There is a period of sustained below average values from 7.9 to 7.6 ka followed by an interval, from 7.5 to $4.1 \mathrm{ka}$, when TOC displays only minor fluctuations. From $4.1 \mathrm{ka}$ to present, there are high amplitude variations in TOC. $\mathrm{C} / \mathrm{N}$ averages 13 and values from 8.7 to 4.1 ka are generally below average, followed by more variability and sharp increases up to 20 after $4.1 \mathrm{ka}$. $\delta^{13} \mathrm{C}$ values show an overall decreasing trend across the record from $-25 \%$ o to $-29 \%$, superimposed by lower amplitude $(\sim 1 \%)$ centennial-scale variability prior to $4.1 \mathrm{ka}$ and greater variability (on the order of $3 \%$ ) after $4.1 \mathrm{ka}$.

The most notable feature among these records is that they all show increased variability after 4.1 ka (Figure 5), coincident with major changes in magnetic susceptibility. The largest variations occur from 3.9 to $3.6 \mathrm{ka}, 2.6$ to $2.1 \mathrm{ka}, 1.9$ to $1.8 \mathrm{ka}, 1.6$ to $1.2 \mathrm{ka}$, and 0.4 to $0.2 \mathrm{ka}$ (shaded in Figure 5). During these periods, magnetic susceptibility increases, $\mathrm{C} / \mathrm{N}$ values generally increase, and $\delta^{13} \mathrm{C}$ values are more positive, except for the interval from 0.5 to $0.3 \mathrm{ka}$. TOC values show sharp decreasing trends from 3.9 to 3.6 $\mathrm{ka}, 2.7$ to $2.5 \mathrm{ka}$, and 0.5 to $0.2 \mathrm{ka}$, but similarly distinct increasing trends $1.9-1.8 \mathrm{ka}$ and $1.5-1.3 \mathrm{ka}$.

The trends in bulk organic matter properties in Flower Valley Lake indicate changes in the source and delivery of organic matter to the lake and provide evidence for changes in DIC during the Holocene. Organic matter in lakes can be derived from terrestrial and aquatic sources and used to reconstruct characteristics of landscape vegetation, aquatic organisms, or changes in the relative input from each source (Meyers, 2003). TOC can indicate changes in primary productivity in the lake driven by nutrient availability, lake water temperature, or the input of terrestrialderived organic matter. The TOC content can also be influenced by dilution from the input of clastic sediment. $\mathrm{C} / \mathrm{N}$ provides information on the relative proportion of aquatic- versus terrestrialderived organic matter. $\mathrm{C} / \mathrm{N}$ values between 4 and 10 are typical of lake algae whereas higher $\mathrm{C} / \mathrm{N}$ values can be attributed to a greater contribution by terrestrial plants (Meyers, 2003). $\delta^{13} \mathrm{C}$ 


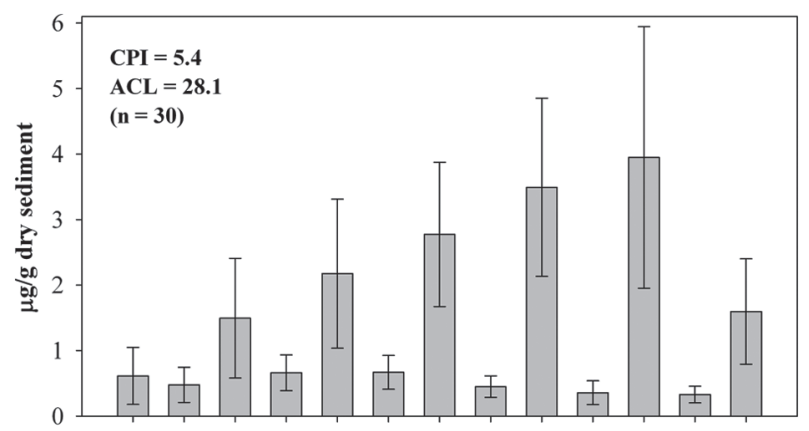

$\begin{array}{llllllllllllll} & \mathrm{C} 21 & \mathrm{C} 22 & \mathrm{C} 23 & \mathrm{C} 24 & \mathrm{C} 25 & \mathrm{C} 26 & \mathrm{C} 27 & \mathrm{C} 28 & \mathrm{C} 29 & \mathrm{C} 30 & \mathrm{C} 31 & \mathrm{C} 32 & \mathrm{C} 33\end{array}$ n-alkanes

Figure 6. Average concentration of $C_{21}-C_{33}$-alkanes.

values can indicate changes in aquatic productivity, because of the preferential use of the lighter ${ }^{12} \mathrm{C}$ by algae during photosynthesis, but can also indicate changes in the $\delta^{13} \mathrm{C}$ dissolved inorganic carbon (DIC) available to algae. Lacustrine algae and $\mathrm{C}_{3}$ land plants typically have $\delta^{13} \mathrm{C}$ values in the range of $-25 \%$ to $-30 \%$ (Meyers, 2003).

In Flower Valley Lake, during the early part of the record (8.8$4.1 \mathrm{ka}), \mathrm{C} / \mathrm{N}$ values indicate the organic content is from a mix of terrestrial and aquatic sources and show only small fluctuations in their relative contributions. Large variations in TOC from 8.8 to $7.5 \mathrm{ka}$ show changes in the input of organic carbon from both sources. After $4.1 \mathrm{ka}$, the sharp increases in $\mathrm{C} / \mathrm{N}$ show periods with greater terrestrial input. The coincident peaks in magnetic susceptibility show that these intervals are also characterized by greater clastic input and the corresponding decreases in TOC indicate dilution by clastic sediment. Peaks in $\delta^{13} \mathrm{C}$ values also likely reflect terrestrial-sourced organic matter, while the long-term decline in $\delta^{13} \mathrm{C}$ can be attributed to a gradual change in the $\delta^{13} \mathrm{C}$ of lake water DIC used by aquatic photosynthetic organisms. A progressive increase in vegetation cover and soil development in the catchment following deglaciation would have promoted more recycling of carbon and led to a decrease in the $\delta^{13} \mathrm{C}$ values of DIC delivered to the lake. This, in turn, would have caused $\delta^{13} \mathrm{C}$ values of aquatic organic matter to decrease. Periodic inputs of terrestrial plants are reflected as deviations from this trend toward higher $\delta^{13} \mathrm{C}$ values.

\section{Composition and sources of sedimentary n-alkanes}

The hydrocarbon fraction is composed of $\mathrm{C}_{16}$ to $\mathrm{C}_{33} n$-alkanes with a strong odd-over-even preference (CPI $=3.3$ to 8.9 ), which is typical of organic matter from terrestrial higher plants (Figure 6). The dominant homologues are $n-\mathrm{C}_{29}$ and $n-\mathrm{C}_{31}$ and ACL ranges from 27 to 30 (Figure 7). Short-chain $n$-alkanes $\left(\mathrm{C}_{16}-\mathrm{C}_{20}\right)$ are present in most samples at very low concentration $(<0.6 \mu \mathrm{g} / \mathrm{g}$ dry sediment). There are two distinct covariation trends in the $n$-alkane concentrations in Flower Valley Lake: one among the $n-\mathrm{C}_{29}-\mathrm{C}_{33}$ alkanes (Figure $7 \mathrm{a}$ ) and one among the $n-\mathrm{C}_{21}-\mathrm{C}_{27}$ alkanes (Figure $7 \mathrm{~b}$ ). $n-\mathrm{C}_{29}-\mathrm{C}_{33}$ show minor variations from 8.6 to $4.1 \mathrm{ka}$ and distinct peaks at $3.9 \mathrm{ka}$ and $1.8 \mathrm{ka}$, coincident with increases in $\mathrm{C} / \mathrm{N}$, and $\delta^{13} \mathrm{C}$ values (Figure $7 \mathrm{a}$ ). $n-\mathrm{C}_{21}-\mathrm{C}_{27}$ alkanes show changes in concentration similar to trends in TOC during the earliest part of the record, with high concentration from 8.3 to 8.0 ka followed by a decrease c. $7.7 \mathrm{ka}$ (Figure $7 \mathrm{~b}$ ). There are only minor changes in concentration of $n-\mathrm{C}_{21}-\mathrm{C}_{27}$ from 7.7 to $3.9 \mathrm{ka}$, after which time variability increases. Increases in ACL and CPI correspond to higher concentrations of $n-\mathrm{C}_{29}-\mathrm{C}_{33}$ (Figure 7c). The $\mathrm{CPI}$ also has a long-term decreasing trend, similar to that exhibited by $\delta^{13} \mathrm{C}$ (Figure 5). There is a significant correlation between the two parameters $\left(R^{2}=0.6\right)$, showing a relationship between $\delta^{13} \mathrm{C}$ and the decrease in the odd-over-even preference of the $n$-alkanes (Figure 8).

$n$-alkanes are produced by algae, photosynthetic bacteria, and aquatic plants living in the lake, as well as terrestrial plants living within the lake's catchment (Meyers, 2003). $n$-alkanes with shortchain lengths, $\mathrm{C}_{15}-\mathrm{C}_{19}$, are typically produced by algae and photosynthetic bacteria (Cranwell et al., 1987, Meyers, 2003). $\mathrm{C}_{23}$ and $\mathrm{C}_{25} n$-alkanes have been found to be the dominant chain length for submerged and floating macrophytes (Ficken et al., 2000; Hou et al., 2006), and chain lengths longer than $C_{25}$ typically derive from terrestrial vascular plant leaf waxes (Cranwell et al., 1987; Eglinton and Hamilton, 1967; Meyers, 2003).

The distinct covariation trends among the $n-\mathrm{C}_{29}-\mathrm{C}_{33}$ (Figure $7 \mathrm{a}$ ) and $n-\mathrm{C}_{21}-\mathrm{C}_{27}$ alkanes (Figure $7 \mathrm{~b}$ ) suggest that these groups of $n$-alkanes derive from different sources. We attribute the midchain length $n$-alkanes to aquatic macrophytes and the longerchain length compounds to terrestrial vascular plants; however the $n-\mathrm{C}_{27}$ alkane shows more similarity to the mid-chain homologues, suggesting significant contribution from macrophytes. The similar trends among $\mathrm{C} / \mathrm{N}$ values, $\mathrm{ACL}$, and $\delta^{13} \mathrm{C}$ values (Figure 8) support this interpretation of $n$-alkane source for this record. The correlation among these variables is best explained by variations in the relative amount of terrestrial organic matter input to the lake. Derivation from different plant communities also helps explain the different trends observed in the $n$-alkane $\delta D$ records (Figure 7d).

\section{$\delta D$ of n-alkanes}

$\delta D$ values of $n-\mathrm{C}_{25}$ and $n-\mathrm{C}_{27}\left(\delta D_{25}\right.$ and $\left.\delta D_{27}\right)$ range from $-172 \%$ to $-212 \%$. $\delta D$ values of $n-\mathrm{C}_{29}$ and $n-\mathrm{C}_{31}\left(\delta D_{29}\right.$ and $\left.\delta D_{31}\right)$ range from -198 to $-214 \%$ (Figure $7 \mathrm{~d}$ ) and have low variance and identical Holocene means $(-204 \pm 3 \%$ and $-205 \pm 3 \%$, respectively; Figure 7d), suggesting they are sourced from the same terrestrial plants. Holocene means of $\delta D_{25}$ and $\delta D_{27}(-191 \pm 9 \%$ and -194 $\pm 4 \%$, respectively) are more positive (D-enriched) relative to $\delta D_{29}$ and $\delta D_{31}$, and show a steady decrease from 8.5 to $4.1 \mathrm{ka}$. $\delta D_{25}$ decreases from $-172 \%$ to $-193 \%$, and $\delta D_{27}$ from $-184 \%$ o to $-194 \%$ across this interval. $\delta D_{27}$ values are intermediate between those of the long-chain $\left(\delta D_{29}\right.$ and $\left.\delta D_{31}\right)$ and mid-chain $\left(\delta D_{25}\right)$ homologues for the majority of the record, suggesting sedimentary $n-C_{27}$ contributions from both terrestrial plants and aquatic macrophytes.

$\delta D$ values of long-chain $n$-alkanes $\left(\delta D_{\text {wax }}\right)$ reflect $\delta D$ of water used by terrestrial vegetation after modification by biosynthetic processes (Sachse et al., 2012 and references therein). Soil moisture provides the source water for terrestrial plants, while lake water is the source for aquatic macrophytes and algae. $\delta D$ of water in soils can be modified to some extent from $\delta D$ of annual precipitation by evaporation. However, it has been shown that $\delta D_{\text {wax }}$ is unaltered by plants following leaf formation and therefore reflects $\delta D_{\text {water }}$ used during leaf flush (Kahmen et al., 2011; Sachse et al., 2010; Tipple et al., 2013). In the Arctic, the majority of leaf formation takes place in late spring/early summer following the return of appreciable sunlight. Because snowmelt is the predominant water source available to plants at the time of leaf formation, the $\delta D_{\text {wax }}$ is potentially biased toward wintertime $\delta D_{\mathrm{p}}$ (i.e. snowfall months). In Tasiilaq, the difference between precipitation-weighted annual average $\delta D_{\mathrm{p}}(-92 \%)$ and precipitationweighted average $\delta D_{\mathrm{p}}$ during months with below zero average temperatures (October-April; -96\%) is negligible (Bowen, 2008; Cappelen et al., 2011), and thus, any changes in the timing of leaf formation during the Holocene, or in the seasonality of precipitation, are unlikely to have had much impact on $\delta D_{\text {wax }}$.

Surface waters tend to be isotopically enriched (i.e. have a more positive $\delta D$ ) relative to precipitation, which has been shown for numerous locations in the Arctic (Gibson et al., 


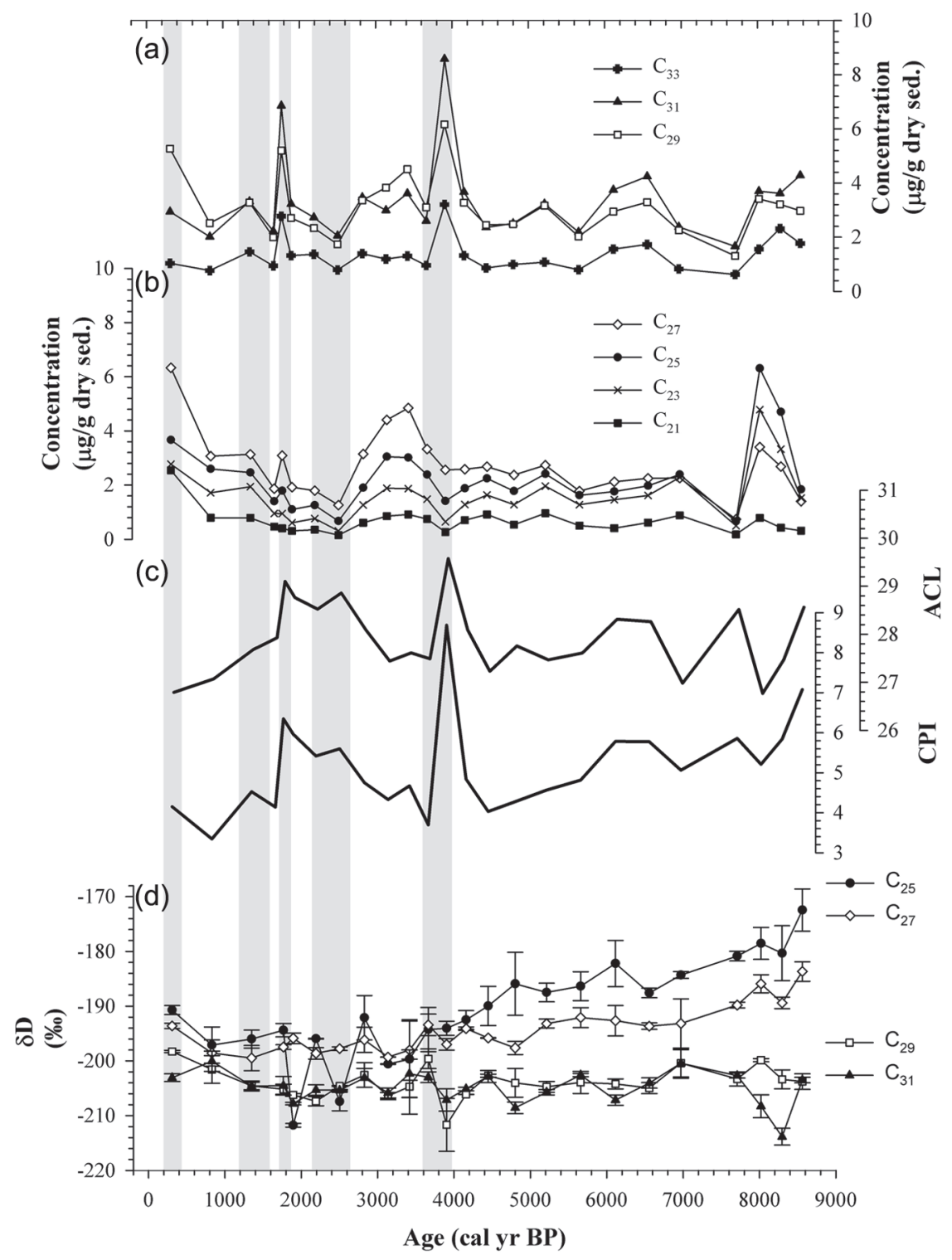

Figure 7. Concentration of (a) long-chain length, and (b) mid-chain length $n$-alkanes. (c) The average chain length (ACL), and Carbon Preference Index (CPI) of $\mathrm{C}_{21}-\mathrm{C}_{33} n$-alkanes. (d) Hydrogen isotopic composition of mid-and long-chain length $n$-alkanes. Error bars reflect the analytical uncertainty $( \pm$ I standard deviation) of replicate measurements. Gray bars indicate intervals of greater input of clastic sediment and terrestrial-derived organic matter.

1993, 2002; Leng and Anderson, 2003). The extent of isotopic enrichment of surface waters from meteoric water is determined by the degree of evaporative enrichment of the water body (Leng and Anderson, 2003). Therefore, $\delta D_{\text {wax }}$ tracks $\delta D_{\mathrm{p}}$ and the $\delta D$ of lipids produced by aquatic plants $\left(\delta D_{\text {aq }}\right)$ tracks the degree of evaporative isotopic enrichment of lake water from meteoric water.

$\delta D_{\mathrm{p}}$ can be estimated from $\delta D_{\text {wax }}$ using the relationship:

$$
\delta D_{p}=\left(\frac{\delta D_{w a x}+1}{\varepsilon_{a p p}+1}-1\right)
$$

where $\varepsilon_{\text {app }}$ is the apparent isotopic fractionation of $\delta D$ between precipitation and leaf wax (note that a factor of 1000 would need to be added to this equation for $\delta D_{\text {wax }}$ and $\varepsilon_{\text {app }}$ values reported as per mil). Using $-205 \%$ as the average $\delta D$ for long-chain alkanes (both $\mathrm{C}_{29}$ and $\mathrm{C}_{31}$ ) and the empirically derived value of $-121 \%$ for $\varepsilon_{\text {app }}$ (Sachse et al., 2012), we derive the value $-95 \%$ for $\delta D_{\mathrm{p}}$. This estimate falls within the range of $\delta D_{\mathrm{p}}$ reported from the closest GNIP station at Groennedal ( -42 to $-134 \%$ ) during the 1960s (IAEA/
WMO, 2006) and is very close to the precipitation-weighted annual average $\delta D_{\mathrm{p}}$ of $-92 \%$ and the precipitation-weighted OctoberApril (freezing months) average $\delta D_{\mathrm{p}}$ of $-96 \%$, determined using interpolated GNIP data (Bowen, 2008) and Tasiilaq meteorological data (Cappelen et al., 2011). We note that the largest source of uncertainty in estimating $\delta D_{\mathrm{p}}$ from $\delta D_{\text {wax }}$ is the uncertainty in $\varepsilon_{\text {app }}$ between precipitation and leaf wax $\left(\varepsilon_{\mathrm{app}}=-121 \%, 1 \sigma=32 \%, n=\right.$ 316; Sachse et al., 2012). The large variance in published $\varepsilon_{\text {app }}$ values likely stems from (1) the poor constraint on $\delta D_{\mathrm{p}}$ values used to determine $\varepsilon_{\text {app }}$, and (2) differences in the evaporative isotopic enrichment (in soils and leaves) of source water from precipitation across the large geographical range represented in the modern data set. Much more work is needed to constrain $\varepsilon_{\text {app }}$ for individual plant types and geographical locations, particularly in the Arctic, where there are no available $\varepsilon_{\text {app }}$ data; however, the large uncertainty in $\varepsilon_{\text {app }}$ from the global data compilation (Sachse et al., 2012) and the observed differences among vegetation types (Feakins and Sessions, 2010; Hou et al., 2007) do not pertain to sedimentary deposition at a single location through time. Therefore, in the following discussion we ignore the uncertainty in $\varepsilon_{\text {app }}$ when applying the mean $\varepsilon_{\text {app }}$ value of $-121 \%$ to estimate past $\delta D_{\mathrm{p}}$. 

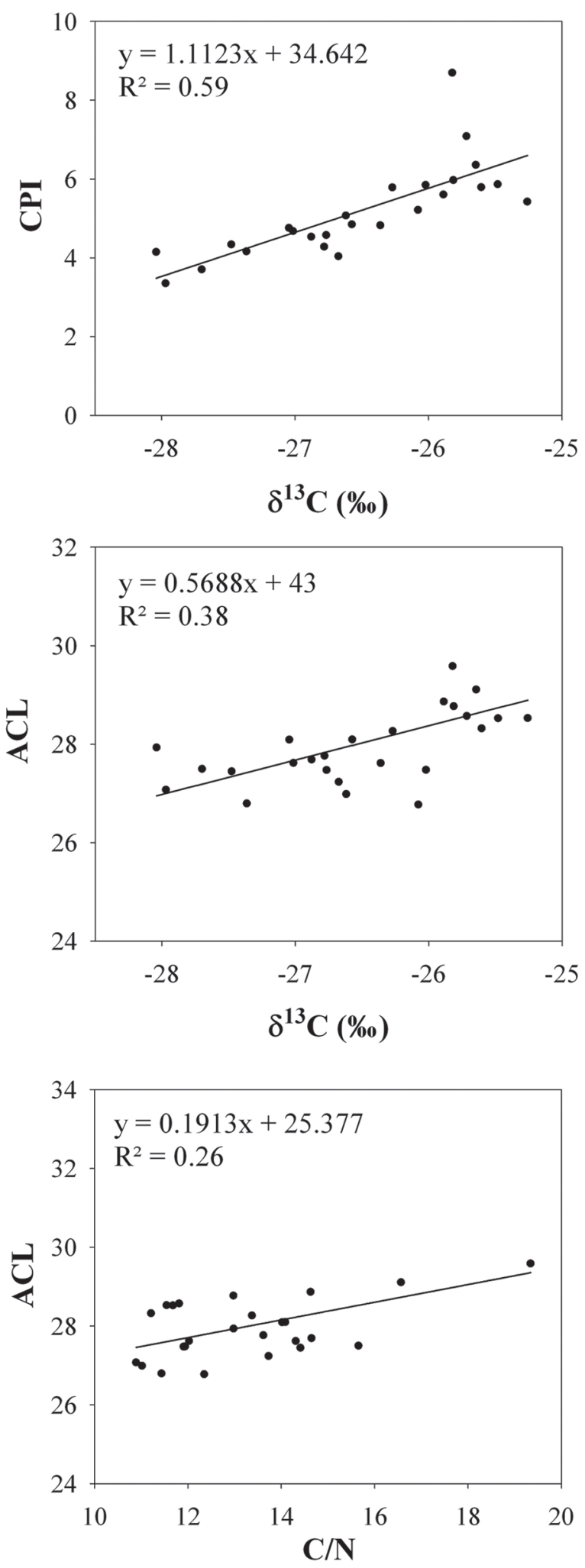

Figure 8. Correlations of $\delta^{13} \mathrm{C}$ and $\mathrm{C} / \mathrm{N}$ with the average chain length $(A C L)$ and the Carbon Preference Index (CPI).

The lack of downcore variability in $\delta D_{29}$ and $\delta D_{31}$ indicates that there has been very little change in the isotopic composition of precipitation used by terrestrial plants in the region during the past $\mathrm{c}$. $8.9 \mathrm{ka}$ (Figure 7d). The relatively $D$-enriched values (more positive $\delta D)$ of $\delta D_{25}$ and $\delta D_{27}$ are consistent with our interpretation that these compounds reflect isotopically enriched lake water. The evaporative isotopic enrichment of lake water can be represented as the apparent isotopic enrichment of lake water-derived lipids from precipitation $\left(\varepsilon_{\mathrm{aq}-\mathrm{p}}\right)$ according to the relationship:

$$
\varepsilon_{a q-p}=\left(\frac{\delta D_{a q}+1}{\delta D_{p}+1}-1\right)
$$

We interpret changes in $\varepsilon_{\text {aq-p }}$ through time as variations in the evaporative isotopic enrichment of lake water. We note that changes in biosynthetic $D / H$ fractionation by aquatic plants and algae could also impact $\varepsilon_{\text {aq-p }}$, but we dismiss this mechanism because there is no evidence for major ecological changes during this time period. Using measured $\delta D_{25}$ values for $\delta D_{\text {aq }}$, and $\delta D_{29}$ values to derive $\delta D_{\mathrm{p}}$ estimates (as described above) we developed a c. 8.9 ka record of $\varepsilon_{\text {aq-p }}$. We find $\varepsilon_{\text {aq-p }}$ is greatest in the early part of the record (beginning c. $8.6 \mathrm{ka}$ ), suggesting this was the time of greatest evaporative enrichment of lake water (Figure 9). From 8.6 to $4.1 \mathrm{ka}$, a steady decrease in $\delta D_{25}$ results in a decrease in $\varepsilon_{\mathrm{aq}-\mathrm{p}}$ from $-86 \%$ to $-108 \%$, and we interpret this as decreasing summertime lake water evaporation. $\varepsilon_{\text {aq-p }}$ remains fairly low after 4.1 $\mathrm{ka}$, with an average value of $-114 \%$, suggesting that this interval was characterized by reduced evaporative enrichment of lake water relative to the period 8.9-4.1 ka. We also note an interval of highly variable $\varepsilon_{\text {aq-p }}$, which encompasses the lowest $\varepsilon_{\text {aq-p }}$ values and therefore the lowest inferred lake water evaporation, from 3.0 to $1.8 \mathrm{ka}$. In summary, the $\delta D$ records reveal that lake water evaporation was highest at the time of deglaciation of Flower Valley (c. $9 \mathrm{ka}$ ), and gradually decreased between 8.5 and 4.1 ka toward present values.

\section{Regional paleoclimate implications}

Holocene climate in the Arctic is characterized by multimillennial-scale trends primarily driven by changes in high latitude summer insolation, which peaked during the early Holocene (12$10 \mathrm{ka}$ ) and gradually declined during the mid to late Holocene (Kaufman et al., 2004; Miller et al., 2010). Around Greenland, the early Holocene is marked by continued retreat of the ice sheet from the continental shelf onto land and into local fjords c. 11-7 ka (Funder et al., 2011b). Maximum summer temperatures were not reached until c. 9-5 ka, because of the cooling influences of the retreating Greenland and Laurentide Ice Sheets on regional oceanic and atmospheric circulation (Kaplan and Wolfe, 2006; Kaufman et al., 2004). Ice-core temperature reconstructions based on oxygen isotopes from the Greenland Ice Sheet indicate temperatures were $2-3^{\circ} \mathrm{C}$ warmer from 9 to $6 \mathrm{ka}$ (Vinther et al., 2009). The Holocene Thermal Maximum was followed by the late-Holocene Neoglacial period, which is characterized by colder conditions and the readvance of the Greenland Ice Sheet c. $5 \mathrm{ka}$ (Funder et al., 2011b). Our record from Flower Valley Lake helps characterize the terrestrial response to Holocene climate changes in southeast Greenland.

The onset of organic sedimentation in Flower Valley Lake, c. $8.4 \mathrm{ka}$, marks the complete deglaciation of the catchment. In southeast Greenland, the retreat of the ice sheet from the continental shelf onto land is only constrained by evidence from outer coastal areas (Long et al., 2008; Roberts et al., 2008). Deglaciation is dated between 11.1 and $9.7 \mathrm{ka}$ based on surface exposure dating near the mouth of Sermilik Fjord (Roberts et al., 2008) and to between 11.0 and $9.5 \mathrm{ka}$, based on the onset of organic sedimentation in lakes above the marine limit just east of Ammassalik Island (Long et al., 2008). The record from Flower Valley Lake( (F) $8.4 \mathrm{ka}$ ) indicates that a small glacier lingered in the cirque above the lake after large fjord glaciers retreated from these outer coastal areas showing a progressive retreat of ice to higher elevations in local valleys.

Initial organic sedimentation in Flower Valley Lake following deglaciation, 8.4-7.0 ka, reflects early lake ontogeny and unstable catchment conditions. This interval is characterized by large 


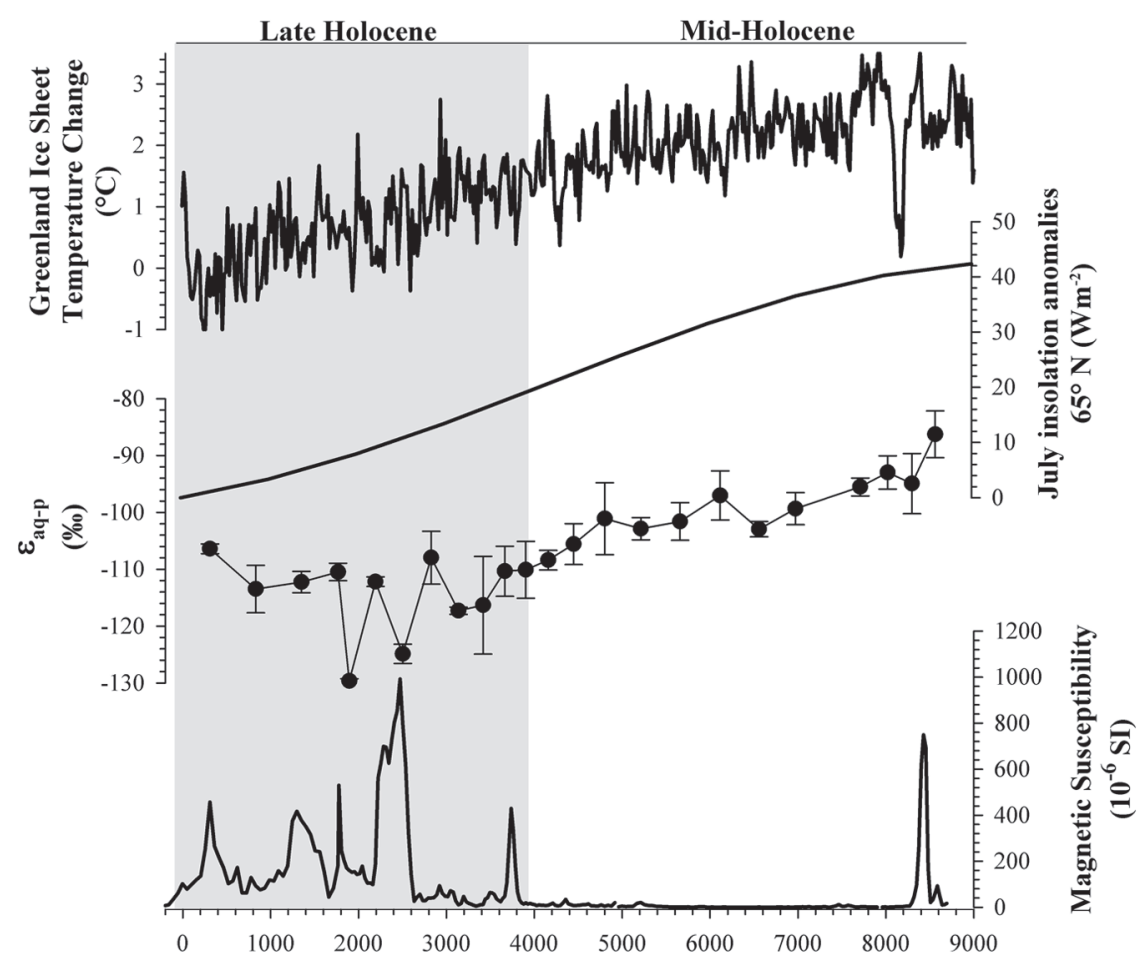

Age (cal yr BP)

Figure 9. Comparison of the records of $\varepsilon_{\mathrm{aq}-\mathrm{p}}$ (apparent isotopic fractionation between reconstructed precipitation and aquatic lipids; error bars are propagated \pm I standard deviations) and magnetic susceptibility from the Flower Valley Lake with July insolation anomalies (Berger and Loutre, 1991) and a Holocene temperature reconstruction for the Greenland Ice Sheet (Vinther et al., 2009).

amplitude variation in TOC, enriched $\delta^{13} \mathrm{C}$ values, a peak in concentration of mid-chain length $n$-alkanes, and the presence of dominantly small benthic diatom assemblages. These properties indicate fluctuations in clastic input, poorly developed soil cover, and reduced autochthonous organic matter production (Figures 4 , $5,7)$. Postglacial landscape development and the timing of the initial establishment of soil and vegetation in the region varied, which can be attributed to local hyrodologic and geomorphic factors. Pollen and sedimentological data from small lakes on the west coast of Ammassalik Island indicate early growth of herbs and other postglacial pioneering plants, followed by the appearance of Empetrum heaths and Salix herbacea c. 9.5 ka (Jakobsen et al., 2008). Bick (1978) dated the onset of peat formation in a mire near the village of Tasiilaq to $5905 \pm 65{ }^{14} \mathrm{C}$ yr BP $(6.7 \mathrm{cal}$. $\mathrm{ka} \mathrm{BP}$ ), although this may have been the result of a change in local hydrologic conditions and stagnation of water.

Over the last $8.4 \mathrm{ka}$, the Flower Valley Lake record is marked by two distinct phases of sedimentation. From 8.4 to $4.1 \mathrm{ka}$, our data show warmer and/or drier climate conditions relative to the last $4.1 \mathrm{ka}$. Higher $\varepsilon_{\mathrm{aq}-\mathrm{p}}$ values indicate greater evaporative enrichment of lake water from 8.4 to $4.1 \mathrm{ka}$ and bulk biogeochemical parameters show that sedimentation was primarily controlled by autochthonous productivity (Figure 9). After $4.1 \mathrm{ka}$, the Flower Valley Lake record shows a shift to persistent wetter or colder conditions marked by an increase in the delivery of terrestrialderived sediment and a decrease in the evaporative enrichment of the lake inferred from $\varepsilon_{\text {aq-p }}$ (Figure 9). $\varepsilon_{\text {aq-p }}$ values fluctuate about a mean value during this interval, with the lowest inferred lake evaporation from 3.0 to $1.8 \mathrm{ka}$, and bulk biogeochemical parameters and concentrations of $n$-alkanes show periodic input of sediment and organic matter from the catchment.

During the mid Holocene, higher insolation and warmer summer temperatures associated with the regional Holocene Thermal Maximum likely resulted in longer ice-free periods promoting greater evaporation of Flower Valley Lake. The period of greatest evaporative enrichment, c. $8.6 \mathrm{ka}$, and the progressive decline in $\varepsilon_{\text {aq-p }}$ from 8.4 to 4.1 ka correspond with the decreasing trend in insolation from the mid to late Holocene (Figure 9). The timing of these drier conditions generally correspond with warmer atmospheric and oceanic temperatures during the regional Holocene Thermal Maximum. Maximum Greenland Ice Sheet temperatures occur from 9 to $6 \mathrm{ka}$ (Vinther et al., 2009), and paleoceanographic data from the southeast Greenland margin indicate warmer sea-surface temperatures from c. 8.5 to $3.5 \mathrm{ka}$ (Andersen et al., 2004; Andrews et al., 1997; Jennings et al., 2011). Diatom-based SSTs in the East Greenland Current indicate the warmest period from 8.5 to $6.5 \mathrm{ka}$ (Andersen et al., 2004). Foraminiferal data show that the warmest interval of the Holocene was 8.1-3.5 ka with a peak in temperatures from 8.1 to $7.1 \mathrm{ka}$ (Jennings et al., 2011) and the interval from 8 to $6 \mathrm{ka}$ is also marked by reduced ice rafting along the east Greenland margin (Andrews et al., 1997). Oceanographic changes are attributed to the increased influence of Irminger Current and a weakening of the East Greenland Current (Jennings et al., 2011).

The continued decline of insolation during the late Holocene led to colder summer temperatures and possibly longer periods of seasonal ice cover at Flower Valley Lake, which likely contributed to a reduction in evaporative enrichment. This was accompanied by the onset of periodic increases in surface runoff, which may have also been the result of colder temperatures and more intense spring melt of accumulated snow. These inferred changes agree with sedimentological and palynological evidence from small lakes on the west coast of Ammassalik Island that indicate longer periods of ice cover and increased snow cover on the landscape beginning c. $4.5 \mathrm{ka}$ (Jakobsen et al., 2008). Changes across the transition from the mid to late Holocene have also been observed in other terrestrial environments in southern and western Greenland, where lake level, macrofossil, stable isotope, and sedimentological data show a shift to wetter conditions and increased surface runoff, c. 6-4 ka (Aebly and Fritz, 2009; Anderson and Leng, 2004; McGowan et al., 2003; Massa et al., 2012; Perren et al., 


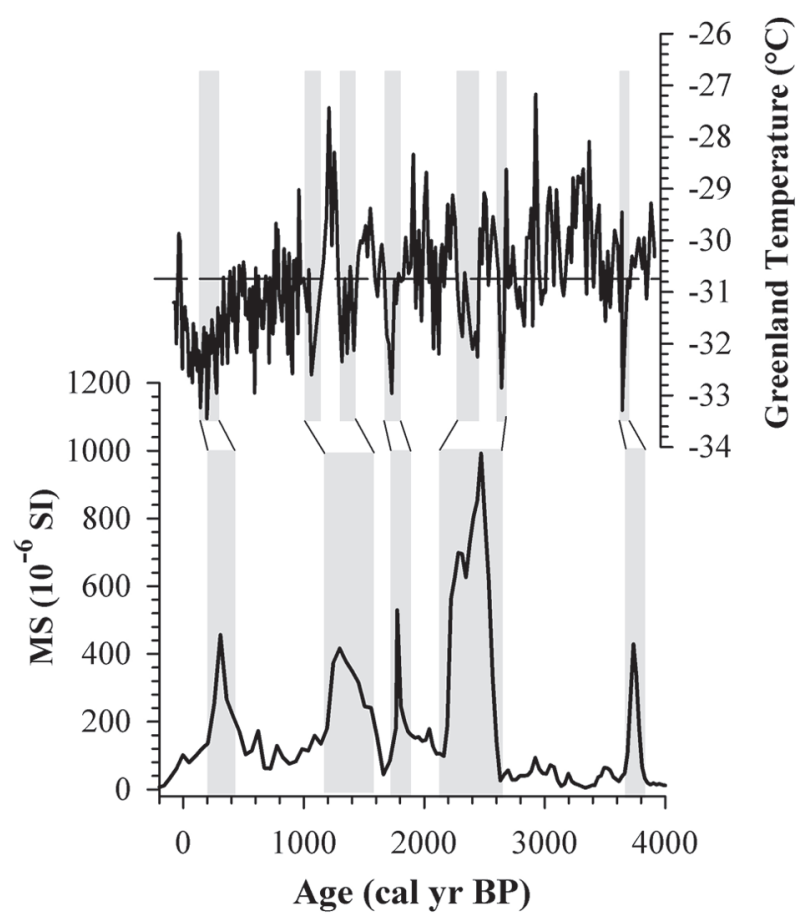

Figure 10. Comparison of the timing of late-Holocene runoff events interpreted from the Flower Valley magnetic susceptibility record to cold periods in reconstructed Greenland surface temperatures over the last $4 \mathrm{ka}$ (Kobashi et al., 20l I).

2012a). Other evidence for the onset of colder conditions associated with the transition to the late-Holocene Neoglacial period occurs slightly later. Marine records indicate an increase in the influence of polar waters on the East Greenland Current and a decrease in strength of the Irminger Current c. 3.6-3.0 ka (Andersen et al., 2004; Andresen et al., 2012; Jennings et al., 2011) and lake sediment records from southern Greenland indicate the onset of colder conditions c. 3.7-3.0 ka (Andresen et al., 2004; Kaplan et al., 2002). There are also similarities in the timing of the intervals of increased surface runoff in Flower Valley Lake and cold periods identified in Greenland Ice Sheet temperatures over the last $4 \mathrm{ka}$ (Figure 10) (Kobashi et al., 2011). The most distinct cold periods in the Kobashi et al. (2011) reconstruction of Greenland temperatures, based on the analysis of nitrogen and argon isotopes of trapped air in ice cores, correspond with runoff events inferred from peaks in magnetic susceptibility. There are minor discrepancies in the timing of events, but they are within the uncertainty of our chronology and indicate the potential response of Flower Valley Lake to centennial-scale regional climate changes.

\section{Conclusions}

Biogeochemical analysis of a sediment record from Flower Valley Lake shows a distinct hydrologic change across the transition from the mid to late Holocene in southeast Greenland. The record shows warmer and drier conditions during the early to mid Holocene, 8.4-4.1 ka, and colder and/or wetter conditions after $4.1 \mathrm{ka}$. These interpretations are based on bulk biogeochemical data and the concentration and isotopic composition of sedimentary $n$-alkanes, which indicate changes in the source of organic matter delivered to the lake and the relative evaporative enrichment of lake water. Warm and dry conditions from 8.4 to 4.1 ka were in response to higher summer insolation and sea-surface temperatures along the southeast Greenland margin corresponding with the regional Holocene Thermal Maximum. Colder and wetter conditions after $4.1 \mathrm{ka}$ are associated with the late-Holocene Neo- glacial period, when insolation was declining and the East Greenland Current had a stronger influence on the region.

\section{Acknowledgements}

We thank Lucien von Gunten for assistance with fieldwork, and Takuro Kobashi for helpful discussions. We also thank Sarah Feakins and one anonymous reviewer for helpful comments on an earlier draft.

\section{Funding}

This project was funded by National Science Foundation grant ARC-0909354 and NOAA grant NA10OAR4310228. D'Andrea's participation was supported by ARC-0851642 to WJD.

\section{References}

Aebly FA and Fritz SC (2009) Palaeohydrology of Kangerlussuaq (Søndre Strømfjord), west Greenland during the last $\sim 8000$ years. The Holocene 19: 91-104.

Andersen C, Koc N, Jennings AE et al. (2004) Non-uniform response of the major surface currents in the Nordic Seas to insolation forcing: Implications for the Holocene climate variability. Paleoceanography 19: PA2003.

Anderson NJ and Leng MJ (2004) Increased aridity during the early Holocene in West Greenland inferred from stable isotopes in laminated-lake sediments. Quaternary Science Reviews 23: 841-849.

Andresen CS, Björk S, Bennike O et al. (2004) Holocene climate changes in southern Greenland: Evidence from lake sediments. Journal of Quaternary Science 19: 783-795

Andresen CS, Hansen MJ, Seidenkrantz M-S et al. (2012) Mid- to late-Holocene oceanographic variability on the Southeast Greenland shelf. The Holocene 23: 167-178.

Andrews JT, Smith LM, Preston R et al. (1997) Spatial and temporal patterns of iceberg rafting (IRD) along the East Greenland margin, ca. $68 \mathrm{~N}$, over the last 14 cal. ka. Journal of Quaternary Science 12: 1-13.

Battarbee RW and Kneen MJ (1982) The use of electronically counted microspheres in absolute diatom analysis. Limnology and Oceanography 27: 184-188.

Berger A and Loutre MF (1991) Insolation values for the climate of the last 10 million years. Quaternary Science Reviews 10: 297-317.

Bick H (1978) A postglacial pollen diagram from Angmagssalik, East Greenland. Meddelelser om Grønland 204: 1-22.

Blaauw M (2010) Methods and code for 'classical' age-modelling of radiocarbon sequences. Quaternary Geochronology 5: 512-518.

Bowen GJ (2008) The Online Isotopes in Precipitation Calculator, Version 2.2. Available from: http://www.waterisotopes.org

Bowen GJ and Revenaugh J (2003) Interpolating the isotopic composition of modern meteoric precipitation. Water Resources Research 39: 1299.

Cappelen J, Laursen EV, Jörgensen PV et al. (2011) DMI Monthly Climate Data Collection 1768-2010, Denmark, The Faroe Islands and Greenland. DMI Technical Report 11-05. Copenhagen: Ministry of Climate and Energy, $54 \mathrm{pp}$.

Castañeda IS and Schouten S (2011) A review of molecular organic proxies for examining modern and ancient lacustrine environments. Quaternary Science Reviews 30: 2851-2891.

Chen JL, Wilson CR and Tapley BD (2006) Satellite gravity measurements confirm accelerated melting of Greenland Ice Sheet. Science 313: 1958-1960.

Cranwell PA, Eglinton G and Robinson N (1987) Lipids of aquatic organisms as potential contributors to lacustrine sediments-II. Organic Geochemistry 11: 513-527.

Daniëls FJA, de Molenaar JG, Chytrý M et al. (2011) Vegetation change in Southeast Greenland? Tasiilaq revisited after 40 years. Applied Vegetation Science 14: 230-241.

Dansgaard W (1964) Stable Isotopes in precipitation. Tellus 16: 436-468.

Douglas MSV, Smol JP and Blake W (1994) Marked post-18th century environmental change in high-arctic ecosystems. Science 266: 416-419.

Eglinton G and Hamilton RJ (1967) Leaf epicuticular waxes. Science 156: 1322-1335.

Feakins SJ and Sessions AL (2010) Controls on the D/H ratios of plant leaf waxes from an arid ecosystem. Geochimica et Cosmochimica Acta 74: 2128-2141.

Ficken KJ, Li B, Swain DL et al. (2000) An n-alkane proxy for the sedimentary input of submerged/floating freshwater aquatic macrophytes. Organic Geochemistry 31: 745-749.

Fritz SC, Engstrom DR and Juggins S (2004) Patterns of early lake evolution in boreal landscapes: A comparison of stratigraphic inferences with a modern chronosequence in Glacier Bay, Alaska. The Holocene 14: 828-840. 
Funder S, Goosse H, Jepsen H et al. (2011a) A 10,000-year record of Arctic Ocean sea-ice variability - View from the beach. Science 333: 747-750.

Funder S, Kjeldsen KK, Kjær KH et al. (2011b) The Greenland Ice Sheet during the past 300,000 years: A review. In: Ehlers J, Gibbard PL and Hughes PD (eds) Developments in Quaternary Science, Vol. 15. Amsterdam: Elsevier, pp. 699-713.

Gardner AS, Moholdt G, Wouters B et al. (2011) Sharply increased mass loss from glaciers and ice caps in the Canadian Arctic Archipelago. Nature 473: 357-360.

Gibson JJ, Edwards TWD, Bursey GG et al. (1993) Estimating evaporation using stable isotopes: Quantitative results and sensitivity analysis for two catchments in northern Canada. Nordic Hydrology 24: 79-94.

Gibson JJ, Prepas EE and McEachern P (2002) Quantitative comparison of lake throughflow, residency, and catchment runoff using stable isotopes: Modeling and results from a regional survey bof Boreal lakes. Journal of Hydrology 262: 128-144.

Hou J, D'Andrea WJ, MacDonald D et al. (2007) Hydrogen isotopic variability in leaf waxes among terrestrial and aquatic plants around Blood Pond, Massachusetts (USA). Organic Geochemistry 38: 977-984.

Hou J, Huang Y, Wang Y et al. (2006) Postglacial climate reconstruction based on compound-specific D/H ratios of fatty acids from Blood Pond, New England. Geochemistry, Geophysics, Geosystems 7: Q03008.

Howat IM, Joughin I and Scambos TA (2007) Rapid changes in ice discharge from Greenland outlet glaciers. Science 315: 1559-1561.

IAEA/WMO (2006) Global network of isotopes in precipitation. The GNIP Database. Available from: http://www.iaea.org/water

Jakobsen BH, Fredskild B and Pedersen JBT (2008) Holocene changes in climate and vegetation in the Ammassalik area, East Greenland, recorded in lake sediments and soil profiles. Geografisk Tidsskrift-Danish Journal of Geography 108: 21-50.

Jennings AE, Andrews JT and Wilson L (2011) Holocene environmental evolution of the SE Greenland Shelf north and south of the Denmark Strait: Irminger and East Greenland current interactions. Quaternary Science Reviews 30: 980-998.

Jennings AE, Knudsen KL, Hald M et al. (2002) A mid-Holocene shift in Arctic sea ice variability on the East Greenland shelf. The Holocene 12: 49-58.

Kahmen A, Dawson TE, Vieth A et al. (2011) Leaf wax n-alkane $\delta$ D values are determined early in the ontogeny of deciduous Populus trichocarpa leaves. Plant, Cell \& Environment 34: 1639-1651.

Kahmen A, Hoffmann B, Schefuss E et al. (2013b) Leaf water deuterium enrichment shapes leaf wax n-alkane delta $\mathrm{D}$ values of angiosperm plants II: Observational evidence and global implications. Geochimica et Cosmochimica Acta 111: 50-63.

Kahmen A, Schefuss E and Sachse D (2013a) Leaf water deuterium enrichment shapes leaf wax n-alkane delta D values of angiosperm plants I: Experimental evidence and mechanistic insights. Geochimica et Cosmochimica Acta 111: 39-49.

Kaplan MR and Wolfe AP (2006) Spatial and temporal variability of Holocene temperature in the North Atlantic region. Quaternary Research 65: 223-231.

Kaplan MR, Wolfe AP and Miller GH (2002) Holocene environmental variability in southern Greenland inferred from lake sediments. Quaternary Research 58: 149-159.

Kaufman DS, Ager TA, Anderson NJ et al. (2004) Holocene thermal maximum in the western Arctic $\left(0-180^{\circ} \mathrm{W}\right)$. Quaternary Science Reviews 23: 529-560.

Kaufman DS, Schneider DP, McKay NP et al. (2009) Recent warming reverses long term Arctic cooling. Science 325: 1236-1239.

Kobashi T, Kawamura K, Severinghaus JP et al. (2011) High variability of Greenland surface temperature over the past 4000 years estimated from trapped air in an ice core. Geophysical Research Letters 38: L21501.

Kinnard C, Zdanowicz CM, Fisher DA et al. (2011) Reconstructed changes in Arctic sea ice over the past 1,450 years. Nature 479: 509-513.

Leng MJ and Anderson NJ (2003) Isotopic variation in modern lake waters from western Greenland. The Holocene 13: 605-611.

Long AJ, Roberts DH, Simpson MJR et al. (2008) Late Weichselian relative sea-level changes and ice sheet history in southeast Greenland. Earth and Planetary Science Letters 272: 8-18.

Luthcke SB, Zwally HJ, Abdalati W et al. (2006) Recent Greenland ice mass loss by drainage systems from satellite gravity observations. Science 314 : $1286-1289$

McGowan S, Ryves DB and Anderson NJ (2003) Holocene records of effective precipitation in West Greenland. The Holocene 13: 239-249.
Massa C, Perren BP, Gauthier E et al. (2012) A multiproxy evaluation of Holocene environmental change from Lake Igaliku, South Greenland. Journal of Paleolimnology 48: 241-258.

Meyers PA (2003) Applications of organic geochemistry to paleolimnological reconstructions: A summary of examples from the Laurentian Great Lakes. Organic Geochemistry 34: 261-289.

Miller GH, Brigham-Grette J, Alley RB et al. (2010) Temperature and precipitation history of the Arctic. Quaternary Science Reviews 29: 1679-1715.

Morison J, Kwok R, Peralta-Ferriz C et al. (2012) Changing Arctic Ocean freshwater pathways. Nature 481: 66-70.

Perren BB, Anderson NJ, Douglas MSV et al. (2012a) The influence of temperature, moisture, and eolian activity on Holocene lake development in West Greenland. Journal of Paleolimnology 48: 223-239.

Perren BB, Wolfe AP, Cooke CA et al. (2012b) Twentieth-century warming revives the world's northernmost lake. Geology 40: 1003-1006.

Peterson BJ, Holmes RM, McClelland JW et al. (2002) Increasing river discharge to the Arctic Ocean. Science 298: 2171-2173.

Polyakov IV, Beszczynska A, Carmack EC et al. (2005) One more step toward a warmer Arctic. Geophysical Research Letters 32: L17605.

Rawlins MA, Steele M, Holland MM et al. (2010) Analysis of the Arctic system for freshwater cycle intensification: Observations and expectations. Journal of Climate 23: 5715-5737.

R Development Core Team (2011) R: A Language and Environment for Statistical Computing. Vienna: R Foundation for Statistical Computing, available from: www.R-project.org

Reimer PJ, Baillie MGL, Bard E et al. (2009) IntCal09 and Marine09 radiocarbon age calibration curves, 0-50,000 years cal BP. Radiocarbon 51: 1111-1150.

Renberg I (1990) A procedure for preparing large sets of diatom slides from sediment cores. Journal of Paleolimnology 4: 87-90.

Rignot E and Kanagaratnam P (2006) Changes in the velocity structure of the Greenland Ice Sheet. Science 311: 986-990.

Roberts DH, Long AJ, Schnabel C et al. (2008) The deglacial history of southeast sector of the Greenland Ice Sheet during the Last Glacial Maximum. Quaternary Science Reviews 27: 1505-1516.

Ryan WBF, Carbotte SM, Coplan JO et al. (2009) Global multi-resolution topography synthesis. Geochemistry Geophysics Geosystems 10: Q0301.

Sachse D, Billault I, Bowen GJ et al. (2012) Molecular paleohydrology: Interpreting the hydrogen-isotopic composition of lipid biomarkers from photosynthesizing organisms. Annual Review of Earth and Planetary Sciences 40: 221-249.

Sachse D, Gleixner G, Wilkes $H$ et al. (2010) Leaf wax n-alkane $\delta$ D values of field-grown barley reflect leaf water $\delta \mathrm{D}$ values at the time of leaf formation. Geochimica et Cosmochimica Acta, 74: 6741-6750.

Sachse D, Radke J and Gleixner G (2004) Hydrogen isotope ratios of recent lacustrine sedimentary n-alkanes record modern climate variability. Geochimica et Cosmochimica Acta 68: 4877-4889.

Seale A, Christoffersen P, Mugford RI et al. (2011) Ocean forcing of the Greenland Ice Sheet: Calving fronts and patterns of retreat identified by automatic satellite monitoring of eastern outlet glaciers. Journal of Geophysical Research 116: F03013.

Spielhagen RF, Werner K, Sørensen SA et al. (2011) Enhanced modern heat transfer to the Arctic by warm Atlantic water. Science 331: 450-453.

Smol JP and Stoermer EF (2010) The Diatoms: Applications for the Environmental and Earth Sciences. Cambridge: Cambridge University Press.

Straneo F, Hamilton GS, Sutherland DA et al. (2010) Rapid circulation of warm subtropical waters in a major fjord in East Greenland. Nature Geoscience 3: 182-186.

Stroeve J, Holland MM, Meier W et al. (2007) Arctic sea ice decline: Faster than forecast. Geophysical Research Letters 34: L09501.

Stuiver M and Reimer PJ (1993) Extended ${ }^{14} \mathrm{C}$ database and revised CALIB radiocarbon calibration program. Radiocarbon 35: 215-230.

Tipple BJ, Berke MA, Doman CE et al. (2013) Leaf-wax n-alkanes record the plant-water environment at leaf flush. Proceedings of the National Academy of Sciences 110: 2659-2664.

Vinther BM, Buchardt SL, Clausen HB et al. (2009) Holocene thinning of the Greenland Ice Sheet. Nature 461: 385-388.

Walker DA, Raynolds MK, Daniëls FJA et al. (2005) The circumpolar Arctic vegetation map. Journal of Vegetation Science 16: 267-282.

Wilson CR, Michelutti N, Cooke CA et al. (2012) Arctic lake ontogeny across multiple interglacials. Quaternary Science Reviews 31: 112-126. 